\title{
Autocrine and Paracrine Actions of IG F-I Signaling in Skeletal Development
}

\author{
Yongmei Wang, Daniel D. Bikle, Wenhan Chang* \\ Endocrine Unit, University of California, San Francisco, Veterans Affairs Medical Center, San Francisco, CA, USA
}

Insulin-like growth factor-I (IGF-I) regulates cell growth, survival, and differentiation by acting on the IGF-I receptor, (IGF-IR)-a tyrosine kinase receptor, which elicits diverse intracellular signaling responses. All skeletal cells express IGF-I and IGF-IR. Recent studies using tissue/cell-specific gene knockout mouse models and cell culture techniques have clearly demonstrated that locally produced IGF-I is more critical than the systemic IGF-I in supporting embryonic and postnatal skeletal development and bone remodeling. Local IGF-I/IGF-IR signaling promotes the growth, survival and differentiation of chondrocytes and osteoblasts, directly and indirectly, by altering other autocrine/paracrine signaling pathways in cartilage and bone, and by enhancing interactions among these skeletal cells through hormonal and physical means. Moreover, local IGF-I/IGF-IR signaling is critical for the anabolic bone actions of growth hormone and parathyroid hormone. Herein, we review evidence supporting the actions of local IGF-I/IGF-IR in the above aspects of skeletal development and remodeling.

Keywords: IGF-I; IGF-IR; signaling; chondrocyte; osteoblast; osteoclast; GH; PTH; CaSR; Calcium-sensing receptor; cell-cell communication

Bone Research (2013) 3: 249-259. doi: 10.4248/BR201303003

\section{Introduction}

Over 50 years ago, Salmon and Daughaday discovered the insulin-like growth factor-I (IGF-I) that has insulin-like signaling properties and can mediate various biologic activities in response to changes in the growth homone $(\mathrm{GH})$ status (1). Since then, there have been a lot of reports on the actions of IGF-I and its receptor (IGF-IR) and binding proteins (IGFBPs) in regulating biological functions in both physiological and pathological states. Originally, IGF-I was considered a key component of the somatomedin hypothesis. Based on this hypothesis, $\mathrm{GH}$, made by pituitary glands, regulates somatic growth by controlling the production of hepatic IGF-I (or somatomedin C), which is then distributed through the circula-

*Correspondence: Wenhan Chang

E-mail: wenhan.chang@ucsf.edu

Tel: 415-221-4810 ext. 3380; Fax: 415-750-6929

Rec eived 23 May 2013; Accepted 29 J une 2013 tion to act on remote target organs/tissues (2). This hypothesis was recently challenged by a number of important disc overies, including a seminal study examining skeletal development in mice with liver-specific deletion of the Igf-I gene (LiverG $\mathrm{F}_{-\mathrm{F}^{-/}}$) (3-4). In the latter mice, the circulating IGF-I level was reduced to less than $25 \%$ of nomal. Despite that, those KO mice developed and grew nomally, and their skeletal changes were minimal (3), suggesting that local IGF-I production is sufficient for supporting general growth and skeletal development. In addition, circulating insulin-like growth factor-II (IGF-II), (another high-affinity ligand to IGF-IR), may also compensate for the loss of systemic IGF-I in these animals. However, the impact of IGF-II on skeletal development is $\mathrm{GH}$-independent and more restric ted to embryogenesis in mice (5-6). All skeletal cells, including chondrocytes, osteoblasts, osteocytes and osteoclasts, express signific ant levels of IGF-I, IGF-II and IGF-IR (7-10). Studies using cell cultures deprived of systemic IGF-I effects and tissue-specific gene knockout (KO) mouse 
models have begun to define the molecular actions of IGF-I and IGF-IR in different bone cell populations. Collectively, these studies indic ate that these molecules constitute complex autocrine/paracrine networks to regulate cell proliferation, survival, and differentiation, controlling the pace of cartilage and bone development and remodeling. This review focuses on recent studies, demonstrating the actions of local IGF-I/IGF-IR signaling in (a) supporting skeletal development and remodeling, (b) cross-talk with other autocrine/paracrine pathways in the bone, (c) mediating cell-cell interactions between various types of skeletal cells, and (d) integration with systemic signals to produce skeletal anabolism

\section{IGF-I, IGF-II, and IGF-IR Signaling Cascades}

IGF-I is a single polypeptide chain consisting of 70 amino acids, which has a binding affinity to IGF-IR 100-fold higher than insulin. IGF-II consists 180 amino acids, which also binds to IGF-IR with a comparable binding affinity as IGF-I. IGF-II also binds to the IGF-II receptor (also named the cation-independent mannose 6-phosphate receptor), which acts as a signaling antagonist to prevent IGF-II responses. IGF-IR consists of two a and two $\beta$ subunits, which are linked by disulfide bonds (11). The a and $\beta$ subunits are cleavage products of a 1367-a mino acid IGF-IR precursor (12). The extracellular a-subunit forms a pocket for IGF-I binding, while the intracellular domain (amino acids 956-1256) of the membranespanning $\beta$-subunit contains a kinase domain (13-14). Upon activation, the tyrosine kinase activity of the IGF-IR entails sequential phosphorylation events at residues Y1135, Y1131, and Y1136, which produce conformational changes in the $\beta$ subunits to create docking sites for downstream signa ling molecules and their phosphorylation (14). Activation of IG F-IR triggers multiple signaling cascades in a cell context-dependent manner to regulate diverse cell functions ranging from proliferation and survival to differentiation into specialized cell lineages. For example, in bone cells and chondrocytes, activated IGF-IRs can recruit members of the insulin receptor substrate (IRS) family (IRS 1-4) directly to their phosphotyrosine-binding (PTB) and SRC homology 2 (SH2) domains, and indirectly to the growth receptor binding protein-2 (Grb2) and the p85 subunit of phosphatidyl inositol 3 kinase (PI3K) through specific motifs within the IRSs (15-17). Both IRS-1 and IRS-2 are required for a full action of IGF-I in bone, but they regulate different functions. Deletion of IRS-1 gene in mice decreases both bone formation and resorption (18), whereas IRS-2 KO mice have reduced bone formation, but increased bone resorption (19), suggesting that different IRSs may be used by different types of bone cells.

Activation of IGF-IR triggers the Ras-Raf-MEK-ERK-MAPK signaling cascade by a series of IRS-dependent protein phosphorylations and complex formations (17, 20). Through the $\mathrm{SH} 2$ domain in the receptor, IGF-IR binds to the $\mathrm{SH} 2$ domain of $\mathrm{Grb2}$, which, in tum, complexes with Sos, a guanine nucleotide exchange factor that mediates GDP/GTP exchange in Ras GTPase, and leads to Ras activation. The activated Ras stimulates Raf kinase to phosphorylate and activa te MAP kinase kinase (MEK), which, in tum, activates ERK1/2 (MAPK1/2) via serine/ threonine phosphorylations of the latter proteins. Activated ERK1/2 enters the nucleus to phosphorylate and activate various transcription factors, leading to increased cyclin D1 expression and reduced p21cip and p27kip expression facilitating cell proliferation.

Activation of IGF-IR/IRS complex also recruits and stimulates the PI3K, which converts PIP2 to PIP3 in the membrane to recruit Akt and associated proteins PDK $1 / 2$, leading to Akt phosphorylation and activation. The activated Akt phosphorylates and inactivates Bad, a pro-apoptotic member of the bcl-2 family, therefore promoting cell survival (17). Akt can also activate mTOR and p70S6 kinase to stabilize beta-catenin to enhance proliferation (21). It has also been shown that hypoxia stimulates PI3K/Akt/mTOR pathway to increase VEGF-A production and promote vascular invasion in the growth plate (22-23), likely in coord ination with IGF-I.

\section{The actions of IGF-I and IGF-IR in skeletal deve- lopment}

Skeletal development is a highly coordinated process, which requires initial recruitment and migration of relevant precursors to future bone sites, commitment of the precursors to chondrogenic and osteogenic lineages and their teminal differentiation to acquire a complete set of cartila ge- or bone-forming functions (24-25). Skeletal patteming, which detemines bone numbers and shapes, is controlled by progenitor recruitment and commitment, while bone growth rates mainly depend on the proliferation, survival and differentiation of chondrogenic and osteogenic cells (24). Recent studies of global and tissue-specific gene $\mathrm{KO}$ mice indicate that IGF-I signaling is more critical in the latter steps of the process, but less in the skeletal patteming.

\section{Studies of global IGF-I and IGF-IR KO mice}

In mouse embryos, the expression of IGF-I and IGF-IR in the skeleton first appears at $13.5 \mathrm{dpc}$ (days post coitus), peaks at $14.5 \mathrm{dpc}$ for IGF-I or $16.5 \mathrm{dpc}$ for IGF-IR, and 
then, slightly declines as gestation proceeds (26). Ablating IGF-I expression in the global IGF-I KO mice causes severe growth retardation, which is evident as early as $13.5 \mathrm{dpc}$ (27-29). The KO mice develop smaller skeletons with a signific ant delay in minera lization at $14.5 \mathrm{dpc}$ and onward. Despite that, all of their skeletal elements are present (26), indicating normal skeletal patteming. The skeletal defects in the $\mathrm{KO}$ mice are caused, at least in part, by reduced proliferation, delayed differentiation and increased apoptosis in the growth plate (26). Most of the IGF-I KO mice die immediately after birth. Studies of the few surviving $\mathrm{KO}$ mice (less than $5 \%$ ), however, show continually retarded bone growth (27-28), suggesting that IGF-I signaling is also essential for skeletal development during post-natal growth. Ablating IGF-IR in the global IGF-IR KO mice produce similar, but more severe growth retardation and skeletal defects than the IGF-I KO mice. Global IGF-I/IGF-IR double KO mice phenocopy the phenotypes of the global IGF-IR KO mice (28). These data suggest that IG F-IR likely mediates all skeletal responses to IGF-I and perhaps the responses to IGF-II during embryonic development.

\section{IGF-I/IGF-IR signaling in chondrogenesis}

Although the above global $\mathrm{KO}$ mice confimed the importance of IGF-I/IGF-IR signaling in supporting skeletal development, they did not specify the action of IGF-I signaling in specific cell lineages in the bone or exclude the impact of other systemic derangements on the skeleton. To define IGF-I/IGF-IR actions in chondrocytes, cartilage-specific IGF-IR KO mouse models (cartIGF-IR-/mice) were made by crossing floxed IGF-IR mice that caried loxP sequences flanking the exon 3 of the gene (30) with mice expressing Cre recombinase transgene, under the control of a type II collagen promoter (31). The growth phenotype of cartlGF-IR--- mice is less severe than the global IGF-IR KO mice. The body weights of newbom cart|GF-IR-1- mice are $\approx 90 \%$ (vs $\approx 45 \%$ for the global IGF-1R KO mice) of their wild-type littemates. Most of the cart|GF-IR-1- mice also die shortly after birth with smaller and less mineralized skeletons. These skeletal phenotypesare caused by severe chondrocyte defects characterized by reduced proliferation, delayed differentiation and hypertrophy and increased apoptosis (32). These data confim the role of IGF-I/IGF-IR signaling in modulating vital functions of chondrocytes and the overall pace of endochondral bone formation in embryos.

The perinatal death of the cart.IGF-IR-1- mice, however, precluded studies of IGF-IR actions in the growth plates during postnatal growth. To address this issue, tamoxifen (Tam)-inducible cartilage-specific IGF-IR KO (TamCarGF-I
$\mathrm{R}^{-1-}$ ) mice were studied (33-34). At 2 weeks of age and 7 to 8 days after the induction of gene $\mathrm{KO}$ by Tam, the TamCanGF-IR ${ }^{-1-}$ mice show significant growth retardation with a body weight that was $\approx 70 \%$ of their control litter mates, and demonstrate severely disorganized growth plates again, due to reduced cell proliferation and delayed differentiation, indicating comparable IGF-IR actions in growth plate development during embryonic and postnatal development (32).

Cross-talk between IGF-I/IGF-IR and parathyroid hormone-related protein (PTHrP) signaling in chondrocytes The PTHrP/Indian Hedgehog (Ihh) feedback loop is a well-established autocrine/parac rine pathway that controls the pace of chondrocyte differentiation (35-37) (Figure 1). PTHrP is made by perichondrial and reserve cells in embryonic skeletons and diffuses into the proliferation zone to activate the type $1 \mathrm{PTH} / \mathrm{PTH}$ rP receptor (PTH1R) in proliferating chondrocytes to susta in their proliferation and delay their maturation (38). When proliferating chondrocytes mature, they increase the production of Ihh, which acts on its receptor Patched in the neighboring cells via unknown mechanisms to increase the production of PTHrP (39), thus slowing down cell differentiation to prevent early closure of the growth plate (Figure 1). During postnatal growth, PTHrP is expressed in maturing/prehypertrophic chondrocytes to support a local autocrine/paracrine interaction. Interestingly, global IGF-I KO, CartlG F-IR-1-, and TamCarG F-IR-1- mice all show increased expression of PTHrP protein and RNA, but decreased Ihh expression in their growth plates, indicating a disnupted PTHrP/Ihh feedback loop $(26,32)$. The increased PTHrP expression could readily contribute to the delayed chondrocyte differentiation and mineralization in these $\mathrm{KO}$ mice, as these chondrocyte defects are also apparent in transgenic mice overexpressing PTHrP (40). However, the latter mice show increased chondrocyte proliferation and decreased apoptosis in their growth plates. On the other hand, blocking IGF-IR signaling in chondrocytes prevents an increase in growth and survival of chondrocytes, which was otherwise expected with increased PTHrP expression. The increased PTHrP expression may represent a failed attempt of the affected chondrocytes to compensate for the reduced proliferation in the IGF-IR KO growth plates. It remains unclear how ablation of IGF-IR leads to the increased PTHrP expression in chondrocytes. Although, Ihh is a critical modulator that promotes PTHrP expression in the growth plate, our observations on the decreased Ihh expression in the Cart|GF-IR ${ }^{-1-}$ and TamCarG F-IR ${ }^{-1-}$ growth plates, however, support an Ihh-independent negative regulation of PTHrP expression and, perhaps, a direct 


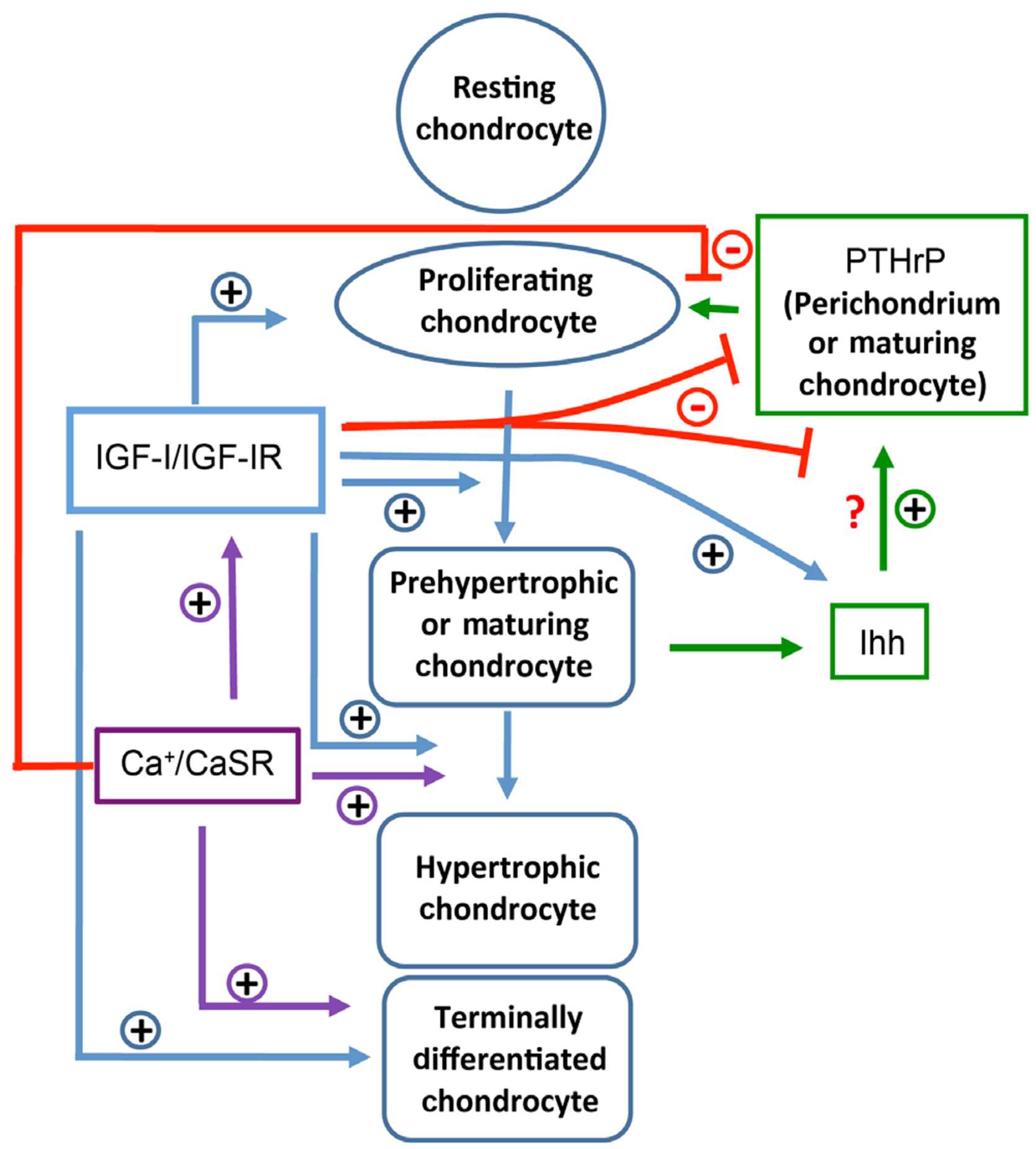

Figure $1 \mathrm{~A}$ schema illustrating the interplays between IGF-I/IGF-IR, PTHrP/Ihh, and $\mathrm{Ca}^{2+} / \mathrm{CaSR}$ signaling pathways in modulating chondrocyte differentiation in the growth plate. IGF-IR signaling promotes cell proliferation, maturation and terminal differentiation, directly (blue arrows) or indirectly, by inhibiting PTHrP expression (red lines). The inhibition of PTHrP could be a direct effect of IGF-I on PTHrP-producing cells, or an indirect effect on the ability of Ihh to increase PTHrP expression. The CaSR begins to express in maturing chondrocytes and its expression level increases as cell differentiation proceeds. $\mathrm{Ca}^{2+} / \mathrm{CaSR}$ signaling increases both IGF-I and IGF-IR. This increased gene expression is required for a full action of CaSR in promoting chondrocyte differentiation, in addition to other IGF-IR-independent effects (purple arrows). See the main text for detailed descriptions of these IGF-I actions. 
effect on Ihh expression by IGF-IR signaling (41) (Figure $1)$.

Cross-talk between IGF-IR and extracellular $\mathrm{Ca}^{2+}$-sensing receptor (CaSR) signaling in chondrocytes

$\mathrm{Ca}^{2+}$ critic ally supports terminal differentiation of chondrocytes and nomal growth plate development. $\mathrm{Ca}^{2+}$ deficiency causeschildhood rickets (42) due to delayed chondrocyte differentiation and reduced ma trix synthesis and minera lization in the growth plates. These defects could be reversed with adequate supplementations of dietary $\mathrm{Ca}^{2+}(43)$, indicating the importance of $\mathrm{Ca}^{2+}$ availability in nomal growth plate development. Studies using chondrogenic cell lines or primary growth plate chondrocytes further, confim direct actions of $\mathrm{Ca}^{2+}$ on the cells to stimulate $G$ protein-mediated signaling responses, and promote teminal differentiation of the cells (44-47).

Studies of cartilage-specific CaSR KO mice and cultured chondrocytes suggest that the CaSR is the molecular basis for extrace llular $\mathrm{Ca}^{2+-s e n s i n g ~ i n ~ c h o n d ~ r o c y t e s ~}$ (44-47). In the growth plate, the CaSR is first expressed in maturing chondrocytes, and its level increases as cells hypertrophy (45). This expression pattem supports a role for the CaSR in mediating terminal differentiation of the cells. In support of this concept, knockdown of CaSR expression blocks the ability of high extracellular $\mathrm{Ca}^{2+}$ concentrations $\left(\left[\mathrm{Ca}^{2+}\right]\right.$ e) to promote cell differentiation and matrix mineralization in cultured chondrocytes (46). Furthermore, Cart $\mathrm{CaSR}^{-/}$mice with cartilage-specific ablation of CaSR gene develop shorter, undermineralized skeletons due to delayed differentiation of hypertrophic chondrocyte (44). Interestingly, the expression of IGF-I and IGF-IR is profoundly reduced in the growth plates of the $\mathrm{Cart}^{\mathrm{C}} \mathrm{CSR}^{-/-}$mice (44), suggesting that $\mathrm{Ca}^{2+}$ CaSR promotes chondrocyte differentiation, at least in part, by enhancing IGF-I signaling (Figure 1). In concordance with this regulatory scheme, ablating IGF-IR genes in cultured chondrocytes inhibits the ability of high $\left[\mathrm{Ca}^{2+}\right.$ e $($ by $\approx 50 \%)$ to enhance terminal differentiation and matrix mineralization, supporting a role for IGF-I/IGF-IR signaling in mediating CaSR-induced chondrocyte differentiation (Figure 1).

Does the $\mathrm{Ca}^{2+} / \mathrm{CaSR}$ signaling pathway also interact with the PTHrP/Ihh feedback loop? In cultured chondrocytes, raising $\left[\mathrm{Ca}^{2+}{ }_{e}\right.$ profoundly inhibits PTHrP and PTH1R expression and blocks the ability of PTHrP to delay cell differentiation and matrix mineralization [(47) and unpublished data]. Furthemore, ablating the IGF-IR gene specifically in growth plate chondrocytes in mice increases their expression of PTHIP, but not PTH1R (32). These observations support a paradigm, in which $\mathrm{Ca}^{2+}$
CaSR signaling counteracts PTHrP/PTH1R signaling by suppressing PTHIR expression, independently, of IGFI/ IGF1R signaling and by inhibiting PTHrP expression via the IGF1/IGF1R pathway to support nomal progression of chondrocyte differentiation and growth plate development (Figure 1).

\section{IGF-I/IGF-IR actions in bone remodeling}

Throughout life, bone is constantly remodeled by cooperative actions of bone-resorbing osteoclasts and bone-forming osteoblasts (48-49). The osteoclasts are derived from hematopoietic stem cells (HSC), while osteoblasts differentiate from bone mamow mesenchymal stem cells (MSC, Figure 2). Bone formation and resorption are tightly balanced to mainta in structural integrity of the bone and to mobilize $\mathrm{Ca}^{2+}$ to meet systemic demands. Studies of global IG F-I KO mice (50-51), which sunvive to adulthood, show decreased bone formation rates, but higher trabecular bone mass (BV/TV), indicating reduction in both osteogenic and osteoclastogenic activities in the bones. These observations support a non-redundant role for IGF-I signaling in bone remodeling. Recent studies of cell-specific IGF-I and IGF-IR KO mice and in vitro cell cultures have begun to reveal detailed molecular actions of those molecules in each population of skeletal cells.

\section{IG F-I signa ling in the osteoblastic lineage}

The osteoblastic lineage begins with mesenchymal progenitors that progress through stages of preosteoblasts (Pre-OB), mature osteoblasts (OB) and, finally, osteocytes $(O C Y$, Figure 2). At each stage, cells express specific markers and unique regulators of cell differentiation. Osteoprogenitors and preosteoblasts express RUNX2 and osterix (OSX), two critic al transc riptional factors that specify cell fates. Preosteoblasts produce large a mounts of type I collagen as a major component of their sumrounding matrix. Mature or fully differentiated osteoblasts, which express osteocalc in (OCN), acquire functions to mineralize the matrix and produce hardened bone. Some mature osteoblasts are, subsequently, embedded in the matrix as osteocytes, which express the dentin matrix protein-1 (DMP-1). Some osteoblasts become quiescent on bone surface and function as lining cells, or otherwise, die by apoptosis (52-53).

In vitro and in vivo studies support a role for the IGF-I signaling in modulating growth, survival, differentiation and minera lizing functions of osteoblasts (Figure 2). In cultures of primary osteoblasts or osteogenic cell lines, IGF-I treatment promotes cell proliferation, differentiation and matrix production (54), and inhibits their apop- 


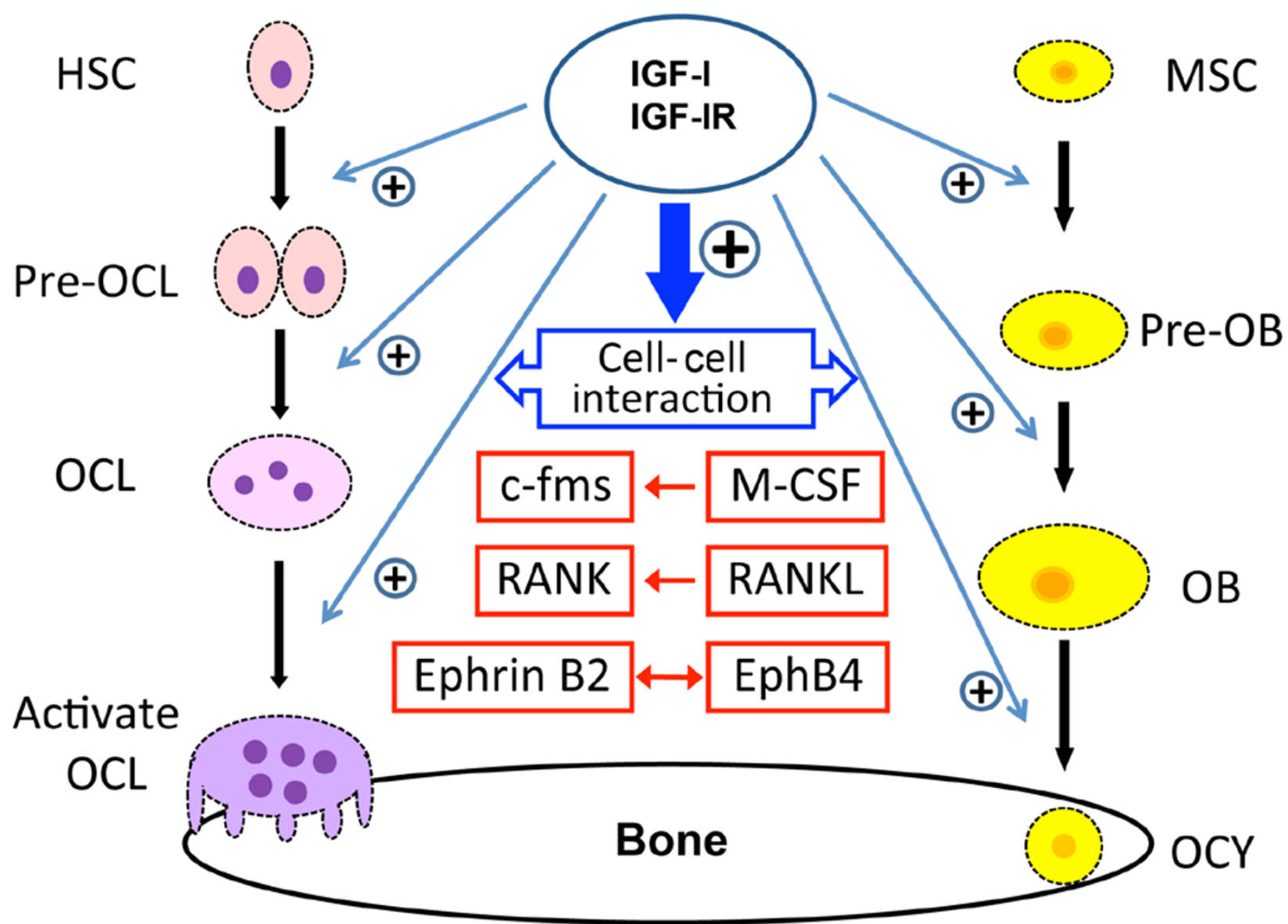

Figure 2 A schema illustrating the actions of IGF-I/IGF-IR signaling in the differentiation of osteoblast and osteoclast in bone. IGF-IR signaling can promote the proliferation, survival, and differentiation of osteoblast (OB), osteocyte (OCY) and osteoclast (OCL), directly (blue arrows) or indirectly, by enhancing cell-cell interactions/couplings between OBs and OCLs, by increasing the expression of critical components in the c-fms/M-CSF, RANK/RANKL and EphrinB2/EphB4 signaling pathways (red boxes and arrows). Red arrows indicate uni- or bi-directional signaling responses mediated by these cell-cell interactions. IGF-IR signaling is also required for mechanosensing in osteocytes. See the main text for detailed descriptions of these IGF-I actions. HSC: hematopoietic stem cell; MSC: mesenchymal stem cells.

tosis (55-56). Deleting IGF-IR at the stage of osteoprogenitor development by Cre-lox recombination using an osterix promoter-driven Cre mouse line, results in delayed osteoblast maturation, matrix synthesis and mineralization, without affecting the differentiation or function of osteoc lasts (57). When IGF-IR is deleted in mature osteoblasts, using OCN promoter-driven Cre line, the KO mice produce less trabecular bone, with an increased proportion of osteoid in the bone, indicating impaired mineralizing functions in OCNIG F-IR-1- osteoblasts (58-59). In contrast, overexpressing IGF-I in mature osteoblasts increases bone formation, with a signific ant decrease in the mineralization lag time (the time for osteoid to be mineralized), but without a change in osteoblast number (60). These data are consistent with a role for IGF-I signaling in promoting osteoblast differentiation in early osteoblasts and enhancing mineralizing activities in mature osteoblasts (60).

Osteocytes make up over $90 \%$ of the cells in bone (61) In addition to their roles in bone development and remodeling, osteocytes are also a source of homonal factors, like FG F23, which modulate mineral homeostasis by acting on distant organs, such as kidney, muscle, parathyroid glands and other tissues (62). DMPIGF-I KO mice, in which the IGF-I gene is deleted in osteocytes using DMP-1 promoter-driven Cre, do not have altered serum IGF-I, calcium, or phophorus levels, but do show decreased serum levels of the bone formation maker procollagen type I N-terminal propeptide (PINP) and the bone resorption marker, c-telopeptide (CTX). These KO 
mice also have reduced trabecular and cortical bone mineral content and decreased osteoclast surface and numbers, but have no change in trabecular bone volume. Interestingly, these mice also showed growth plate defects due to unknown causes (63). Nevertheless, these KO mice fail to respond to mechanical loading in promoting periosteal and endosteal bone formation, and the expression of early mechanoresponsive genes (IGF-I, Cox-2, c-fos), osteogenic markers (RUNX2, and osteocalcin) and canonical Wht signaling genes (Wnt10b, Lp5, Dkk1, sFrp2). The lack of osteogenic response is not due to a reduced osteocyte density (64), suggesting that osteocyte-derived IGF-I not only mediates bone osteoblast/osteocyte differentiation, but also the mechanosensitivity of the cells (Figure 2).

\section{IGF-I/IGF-IR signaling in osteoc lasts}

Studies of global IG F-I KO mice showed fewer (76\% of WT control) and smaller osteoclasts with fewer nuclei in the bone (65), indicating impaired osteoclastogenesis and bone resomtion (Figure 2). These osteoclast defects could explain, at least in part, the increased bone fraction, despite a decreased bone formation rate, in the KO mice described earlier. These osteoclast defects appear to be cell-autonomous, as they could be recapitulated by culturing osteoc last precursors from the global IGF-I KO mice, which showed reduced ability to differentiate into mature osteoclasts (65). Interestingly, co-culturing IGF-I++ osteoclast precursors (spleen cells from WT mice), with IG $\mathrm{F}_{-1}{ }^{-1}$ osteoblasts (bone marrow stromal cells from IGF-I KO mice), produces signific antly fewer (by $\approx 90 \%)$ multi-nucleated osteoclasts than coculturing IG F-IH+ osteoc last precursors with IGF-IH+ osteoblasts, suggesting that osteoblasts may be a source of IGF-I to promote osteoclastogenesis. Similarly, co-culturing IGF-1/- osteoclast precursors, with IGF-IH+ osteoblast precursors, also produces less (by $\approx 50 \%$ ) multinucleated osteoclasts than co-culturing IGF-IH+ osteoclast precursors with IGF-IH+ osteoblasts (65), suggesting that the expression of IGF-I in osteoclast precursors is also required to support the full-scale osteoclastogenesis.

To further define the action of IGF-I signaling on osteoclast differentiation, mice (OCLGF-IR KO) with deletion of IGF-IR gene in osteoclast precursors, were studied. These $\mathrm{KO}$ mice have increased trabecular bone fraction and reduced osteoclast number, as seen in the global IGF-I KO mice. Similarly, ablation of IGF-IR in cultured osteoclast precursors reduces the number and size of osteoclasts and their expression of RANK, c-fms, and NFATc 1 (unpublished data). Taken together, these in vitro and in vivo data, confim an essential role for the IGF-I/IGF-IR signaling in promoting both early- and late-stage osteo- clastogenesis (Figure 2).

\section{IGF-I signaling in skeletal cell-cell interactions}

In addition to their interactions through hormonal factors, like osteoblastic M-CSF, which activates c-fms in osteoclasts, osteoblasts, osteoclasts and chondrocytes, can also communicate with each other through physical interactions using their cell-surface ligands and receptors. These exert uni- or bi-directional signals in the corres ponding cells (Figure 2). For example, osteoblasts express receptor activator of NF-kB (RANK) ligand (RANKL) to activate the RANK on the surface of osteoclast precursors, and induce the differentiation of the latter cells (66). More recent studies have shown that osteoblasts express EphB4, a member of the tyrosine kinase receptor Eph family, as well as its ligand ephrin B2, supporting interactions between osteoblasts. Osteoclasts express ephrin B2, but not EphB4, which enable osteoblast-osteoclast interactions (67). IGF-I stimulates RANKL, ephrin B2 and EphB4 expression in osteoblasts and RANK and EphrinB2 expression in osteoclasts. Changes in the expression of those signaling molecules could be part of the underlying mechanism modulating osteoclastogenesis in response to IGF-I (Figure 2). This concept is supported by the reduced ability (by $\approx 90$ ) of IGF $-1^{-1-}$ osteoblasts to induce osteoclastogenesis of spleen cells cultured from WT mice (65). Furthermore, our recent studies demonstrate that IGF-I treatment enhances the ability of osteoblasts and chondrocytes to induce osteoclast formation in the corresponding co-cultures (osteoblasts/osteoclasts or chondrocytes/osteoc lasts), and this effect could be blocked by a specific peptide that interferes with the EphB4-ephrinB2 interactions (manuscript in submission). These data support a role for IGF-I signaling in skeletal cell-cell interactions by stimulating RANKL/RANK and ephrin B2/EphB4 pathways in the cells (Figure 2).

\section{Integration of local IGF-I/ IGF-IR signaling with systemic homones}

Integration with $\mathrm{GH}$

Although it is well established that $\mathrm{GH}$ stimulates hepatic gene expression to make and supply IGF-I to the circulation, recent studies suggest that changes in circulating IGF-I levels may be an indicator of GH status, but may not be directly involved in controlling local functions in non-hepatic tissues, including bone (68). The fact that chondrocytes and osteoblasts also express growth hormone receptors (GHRs) (69) suggests direct actions of $\mathrm{GH}$ on these cells. Indeed, GH can exert both IGF-Idependent and IGF-I-independent actions to regulate 
bone cell and chondrocyte functions. For example, GH could stimulate ERK and Akt phosphorylation and inhibit apoptosis in cultures of osteoblasts lacking IGF-IR expression, but fail to induce cell proliferation in the same cultures (70). Moreover, we (50) showed that GH could stimulate bone formation even in the global IGF-I KO mice, although not to the extent of IGF-I replacement. Studies by Gan and colleagues showed that GH can promote the formation of GHR/J AK2/IGF-IR complex to facilitate GHR signaling in osteoblasts (71), indicating a novel complementation between GHR and IGF-IR signaling, which could be a basis for some IGF-IR-dependent $\mathrm{GH}$ actions. The fact that OCNIGF-IR KO mice failed to respond to $\mathrm{GH}$ treatment to increase bone mass suggests that IGF-IR-dependent actions of $\mathrm{GH}$ are the predominant responses to promote skeletal anabolism (70). It, however, remains unclear regarding the sources of IGF-I that respond to $\mathrm{GH}$ and promote osteoblast functions in the bone.

$\mathrm{Wu}$ and colleagues generated a compound $\mathrm{KO} /$ transgenic mouse model (GHRKO-HIT) to assess the importance of local IGF-I production for skeletal development (72). In this model, GHR is globally ablated and an IGF-I transgene is expressed in liver to restore serum IGF-I levels. The skeletal IGF-I gene expression was blunted in these mice due to the lack of GHR signaling in the bone. Interestingly, IGF-I produced by the liver failed to reach bone to compensate for local IGF-I deficiency. As a result, GHRKO-HIT mice were growth retarded and had reduced bone growth. These data confirm the importance of locally produced IGF-I in supporting overall skeletal development

Integration with PTH

PTH is a critic al regulator of mineral and skeletal homeostasis. Its effects on bone are complex. Intermittent administration of PTH produc es skeletal a na bolism (73-74) by increasing the growth (75), survival (76) and differentiation of osteoblasts (77). Continuous infusion of $\mathrm{PTH}$, however, is catabolic to bone due to a net increase in bone resorption (78-79). Abundant studies support a non-redundant role for IGF-I signaling in mediatitng anabolic actions of PTH. In osteoblast cultures, PTH stimulates IGF-I production. Neutralizing antibodies for IGF-I block the stimulatory effects of PTH on collagen synthesis (80) and osteoblast differentiation (81). Intermittent PTH fails to elic it skeletal a na bolism in global IGF-I $\mathrm{KO}$ mice $(51,82-83)$, or in mice lacking the expression of IRS-1 (84). Similarly, ablation of IGF-IR in mature osteoblasts prevents the anabolic effects of intemittent $\mathrm{PTH}$ in oCNIGF-IR-/- mice (59). Interestingly, ablating IGF-I in the liverdoes not affect PTH-induced a nabolism in bone (85).
Taken together, these data support the concept that intermittent PTH produces skeletal anabolism by enhancing local IGF-I/IGF-IR signaling in bone.

\section{Conclusions}

IGF-I signaling is critical for all aspects of skeletal development and remodeling. The major signaling pathways for IGF-I are mediated by IGF-IR, which initiates both the MAPK and PI3K pathways that regulate diverse cellular functions. During embryonic and postnatal bone development, IGF-I signaling critically modulates chondrocyte growth, survival and differentiation, at least partly, by inhibiting PTHrP production and enhancing CaSR signaling. In bone, IGF-I is a critical regulator of growth, survival, differentiation and mineralizing functions of osteoblasts. IGF-I also regulates the mechanosensitivity of osteocytes. IGF-I signaling is required for the skeletal cell communications through RANKL/RANK, M-CSF/ C-fms and ephrin B2/EphB4 signaling. Moreover, local IGF-I production and IGF-IR signaling a re essential for the anabolic actions of PTH and GH.

\section{Future directions}

At least five important questions regarding local IGF-I/ IG F-IR signaling warrant future investigation: 1) What a re the local sourc es of IG F-I controlling chondorcyte, osteoblast and osteoclast functions? 2) How do systemic GH and PTH signals mediate IGF-I expression and IGF-IR signaling? 3) How does IG F-I signaling interact with other a utoc rine/parac rine signals, like Wnt, ephrins, BMP, TGFß and other bone regulating molecules? 4) How does a change in IGF-I signaling contribute to disease states, like osteoporosis, osteoarthritis, bone cancer metastasis and fracture healing? 5) Finally, and perhaps most importantly, how can we translate those basic research findings into clinical uses to prevent and treat skeletal diseases?

\section{Acknowledgments}

This work was supported by NIH grants RO1 AG021353 (W.C.), AR055924 (D.B), DK 054793 (D.B.), and by the Department of Veteran Affairs Program Project Award Program in Bone Disease and Menit Review Grants (W.C., D.B.).

\section{References}

1 Salmon WD Jr, Daughaday WH. A hormonally controlled serum factor which stimulates sulfate incorporation by cartilage in vitro. 
J Lab Clin Med. 1957;49:825-836.

2 Daughaday WH, Hall K, Raben MS, Salmon WD Jr, van den Brande JL, van Wyk JJ. Somatomedin: proposed designation for sulphation factor. Nature. 1972;235:107.

3 Yakar S, Liu JL, Stannard B, Butler A, Accili D, Sauer B, LeRoith D. Normal growth and development in the absence of hepatic insulin-like growth factor I. Proc Natl Acad Sci U S A. 1999;96: 7324-7329.

4 Sjogren K, Jansson JO, Isaksson OG, Ohlsson C. A model for tissue-specific inducible insulin-like growth factor-I (IGF-I) inactivation to determine the physiological role of liver-derived IGF-I. Endocrine. 2002;19:249-256.

5 DeChiara TM, Efstratiadis A, Robertson EJ. A growth-deficiency phenotype in heterozygous mice carrying an insulin-like growth factor II gene disrupted by targeting. Nature. 1990;345:78-80.

6 DeChiara TM, Robertson EJ, Efstratiadis A. Parental imprinting of the mouse insulin-like growth factor II gene. Cell. 1991;64:849859 .

7 Lazowski DA, Fraher LJ, Hodsman A, Steer B, Modrowski D, Han VK. Regional variation of insulin-like growth factor-I gene expression in mature rat bone and cartilage. Bone. 1994;15:563576.

8 Hou P, Sato T, Hofstetter W, Foged NT. Identification and characterization of the insulin-like growth factor I receptor in mature rabbit osteoclasts. J Bone Miner Res. 1997;12:534-540.

9 Wang E, Wang J, Chin E, Zhou J, Bondy CA. Cellular patterns of insulin-like growth factor system gene expression in murine chondrogenesis and osteogenesis. Endocrinology. 1995;136:27412751.

10 Reijnders CM, Bravenboer N, Tromp AM, Blankenstein MA, Lips P. Effect of mechanical loading on insulin-like growth factor-I gene expression in rat tibia. J Endocrinol. 2007;192:131-140.

11 Massague J, Czech MP. The subunit structures of two distinct receptors for insulin-like growth factors I and II and their relationship to the insulin receptor. J Biol Chem. 1982;257:5038-5045.

12 Ullrich A, Gray A, Tam AW, Yang-Feng T, Tsubokawa M, Collins C, Henzel W, Le Bon T, Kathuria S, Chen E, et al. Insulin-like growth factor I receptor primary structure: comparison with insulin receptor suggests structural determinants that define functional specificity. Embo J. 1986;5:2503-2512.

13 Sasaki N, Rees-Jones RW, Zick Y, Nissley SP, Rechler MM. Characterization of insulin-like growth factor I-stimulated tyrosine kinase activity associated with the beta-subunit of type I insulin-like growth factor receptors of rat liver cells. J Biol Chem. 1985;260:9793-9804.

14 Favelyukis S, Till JH, Hubbard SR, Miller WT. Structure and autoregulation of the insulin-like growth factor 1 receptor kinase. Nat Struct Biol. 2001;8:1058-1063.

15 Myers MG, Jr., Backer JM, Sun XJ, Shoelson S, Hu P, Schlessinger J, Yoakim M, Schaffhausen B, White MF. IRS-1 activates phosphatidylinositol 3'-kinase by associating with src homology 2 domains of p85. Proc Natl Acad Sci U S A. 1992;89:10350-10354.
16 Myers MG Jr, Sun XJ, Cheatham B, Jachna BR, Glasheen EM, Backer JM, White MF. IRS-1 is a common element in insulin and insulin-like growth factor-I signaling to the phosphatidylinositol 3'-kinase. Endocrinology. 1993;132:1421-1430.

17 Le Roith D, Bondy C, Yakar S, Liu JL, Butler A. The somatomedin hypothesis: 2001. Endocr Rev. 2001;22:53-74.

18 Ogata N, Chikazu D, Kubota N, Terauchi Y, Tobe K, Azuma Y, Ohta T, Kadowaki T, Nakamura K, Kawaguchi H. Insulin receptor substrate- 1 in osteoblast is indispensable for maintaining bone turnover. J Clin Invest. 2000;105:935-943.

19 Akune T, Ogata N, Hoshi K, Kubota N, Terauchi Y, Tobe K, Takagi H, Azuma Y, Kadowaki T, Nakamura K, Kawaguchi H. Insulin receptor substrate-2 maintains predominance of anabolic function over catabolic function of osteoblasts. J Cell Biol. 2002; 159:147-156.

20 LeRoith D, Werner H, Beitner-Johnson D, Roberts CT Jr. Molecular and cellular aspects of the insulin-like growth factor I receptor. Endocr Rev. 1995;16:143-163.

21 Playford MP, Bicknell D, Bodmer WF, Macaulay VM. Insulin-like growth factor 1 regulates the location, stability, and transcriptional activity of beta-catenin. Proc Natl Acad Sci U S A. 2000;97: 12103-12108.

22 Akeno N, Robins J, Zhang M, Czyzyk-Krzeska MF, Clemens TL. Induction of vascular endothelial growth factor by IGF-I in osteoblast-like cells is mediated by the PI3K signaling pathway through the hypoxia-inducible factor-2alpha. Endocrinology. 2002;143:420-425.

23 Schipani E, Maes C, Carmeliet G, Semenza GL. Regulation of osteogenesis-angiogenesis coupling by HIFs and VEGF. J Bone Miner Res. 2009;24:1347-1353.

24 Hall BK, Miyake T. All for one and one for all: condensations and the initiation of skeletal development. Bioessays. 2000;22: 138-147.

25 Horton WA. Skeletal development: insights from targeting the mouse genome. Lancet. 2003;362:560-569.

26 Wang Y, Nishida S, Sakata T, Elalieh HZ, Chang W, Halloran BP, Doty SB, Bikle DD. Insulin-like growth factor-I is essential for embryonic bone development. Endocrinology. 2006;147:47534761.

27 Powell-Braxton L, Hollingshead P, Warburton C, Dowd M, Pitts-Meek S, Dalton D, Gillett N, Stewart TA. IGF-I is required for normal embryonic growth in mice. Genes Dev. 1993;7:26092617.

28 Liu JP, Baker J, Perkins AS, Robertson EJ, Efstratiadis A. Mice carrying null mutations of the genes encoding insulin-like growth factor I (Igf-1) and type 1 IGF receptor (Igf1r). Cell. 1993;75:59-72.

29 Baker J, Liu JP, Robertson EJ, Efstratiadis A. Role of insulin-like growth factors in embryonic and postnatal growth. Cell. 1993;75: 73-82.

30 Dietrich P, Dragatsis I, Xuan S, Zeitlin S, Efstratiadis A. Conditional mutagenesis in mice with heat shock promoter-driven cre transgenes. Mamm Genome. 2000;11:196-205.

31 Horton W, Miyashita T, Kohno K, Hassell JR, Yamada Y. Identi- 
fication of a phenotype-specific enhancer in the first intron of the rat collagen II gene. Proc Natl Acad Sci U S A. 1987;84:8864-8868.

32 Wang Y, Cheng Z, Elalieh HZ, Nakamura E, Nguyen MT, Mackem S, Clemens TL, Bikle DD, Chang W. IGF-1R signaling in chondrocytes modulates growth plate development by interacting with the PTHrP/Ihh pathway. J Bone Miner Res. 2011;26: 1437-1446.

33 Metzger D, Li M, Chambon P. Targeted somatic mutagenesis in the mouse epidermis. Methods Mol Biol. 2005;289:329-340.

34 Nakamura E, Nguyen MT, Mackem S. Kinetics of tamoxifenregulated Cre activity in mice using a cartilage-specific CreER(T) to assay temporal activity windows along the proximodistal limb skeleton. Dev Dyn. 2006;235:2603-2612.

35 Vortkamp A, Lee K, Lanske B, Segre GV, Kronenberg HM, Tabin CJ. Regulation of rate of cartilage differentiation by Indian hedgehog and PTH-related protein. Science. 1996;273:613-622.

36 Karp SJ, Schipani E, St-Jacques B, Hunzelman J, Kronenberg H, McMahon AP. Indian hedgehog coordinates endochondral bone growth and morphogenesis via parathyroid hormone relatedprotein-dependent and -independent pathways. Development. 2000;127:543-548

37 Kronenberg HM. Developmental regulation of the growth plate. Nature. 2003;423:332-336

38 Chung UI, Lanske B, Lee K, Li E, Kronenberg H. The parathyroid hormone/parathyroid hormone-related peptide receptor coordinates endochondral bone development by directly controlling chondrocyte differentiation. Proc Natl Acad Sci U S A. 1998;95: 13030-13035.

39 Chung UI, Schipani E, McMahon AP, Kronenberg HM. Indian hedgehog couples chondrogenesis to osteogenesis in endochondral bone development. J Clin Invest. 2001;107:295-304.

40 Weir EC, Philbrick WM, Amling M, Neff LA, Baron R, Broadus AE. Targeted overexpression of parathyroid hormone-related peptide in chondrocytes causes chondrodysplasia and delayed endochondral bone formation. Proc Natl Acad Sci U S A. 1996;93: 10240-10245

41 Long F, Joeng KS, Xuan S, Efstratiadis A, McMahon AP. Independent regulation of skeletal growth by Ihh and IGF signaling. Dev Biol. 2006;298:327-333.

42 Holick MF. Resurrection of vitamin D deficiency and rickets. J Clin Invest. 2006;116:2062-2072.

43 Thacher TD. Calcium-deficiency rickets. Endocr Dev. 2003;6: 105-125.

44 Chang W, Tu C, Chen TH, Bikle D, Shoback D. The extracellular calcium-sensing receptor (CaSR) is a critical modulator of skeletal development. Sci Signal. 2008;1: ra1.

45 Chang W, Tu C, Chen TH, Komuves L, Oda Y, Pratt SA, Miller S, Shoback D. Expression and signal transduction of calciumsensing receptors in cartilage and bone. Endocrinology. 1999;140: 5883-5893.

46 Chang W, Tu C, Pratt S, Chen TH, Shoback D. Extracellular $\mathrm{Ca}(2+)$-sensing receptors modulate matrix production and mineralization in chondrogenic RCJ3.1C5.18 cells. Endocrinology. 2002;143:1467-1474.

47 Rodriguez L, Cheng Z, Chen TH, Tu C, Chang W. Extracellular calcium and parathyroid hormone-related peptide signaling modulate the pace of growth plate chondrocyte differentiation. Endocrinology. 2005;146:4597-4608.

48 Hadjidakis DJ, Androulakis, II. Bone remodeling. Ann N Y Acad Sci. 2006;1092:385-396.

49 Zaidi M. Skeletal remodeling in health and disease. Nat Med. 2007;13:791-801.

50 Bikle D, Majumdar S, Laib A, Powell-Braxton L, Rosen C, Beamer W, Nauman E, Leary C, Halloran B. The skeletal structure of insulin-like growth factor I-deficient mice. J Bone Miner Res. 2001;16:2320-2329.

51 Bikle DD, Sakata T, Leary C, Elalieh H, Ginzinger D, Rosen CJ Beamer W, Majumdar S, Halloran BP. Insulin-like growth factor I is required for the anabolic actions of parathyroid hormone on mouse bone. J Bone Miner Res. 2002;17:1570-1578.

52 Maes C, Kobayashi T, Kronenberg HM. A novel transgenic mouse model to study the osteoblast lineage in vivo. Ann N Y Acad Sci. 2007;1116:149-164

53 Adams SL, Cohen AJ, Lassova L. Integration of signaling pathways regulating chondrocyte differentiation during endochondral bone formation. J Cell Physiol. 2007;213:635-641.

54 Hock JM, Centrella M, Canalis E. Insulin-like growth factor I has independent effects on bone matrix formation and cell replication. Endocrinology. 1988;122:254-260.

55 Hill PA, Tumber A, Meikle MC. Multiple extracellular signals promote osteoblast survival and apoptosis. Endocrinology. 1997;138:3849-3858.

56 Tumber A, Meikle MC, Hill PA. Autocrine signals promote osteoblast survival in culture. J Endocrinol. 2000;167:383-390.

57 Xian L, Wu X, Pang L, Lou M, Rosen CJ, Qiu T, Crane J, Frassica F, Zhang L, Rodriguez JP, Xiaofeng J, Shoshana Y, Shouhong X, Argiris E, Mei W, Xu C. Matrix IGF-1 maintains bone mass by activation of mTOR in mesenchymal stem cells. Nat Med. 2012;18: 1095-1101.

58 Zhang $\mathrm{M}$, Xuan S, Bouxsein ML, von Stechow D, Akeno N, Faugere MC, Malluche H, Zhao G, Rosen CJ, Efstratiadis A, Clemens TL. Osteoblast-specific knockout of the insulin-like growth factor (IGF) receptor gene reveals an essential role of IGF signaling in bone matrix mineralization. J Biol Chem. 2002;277: 44005-44012.

59 Wang Y, Nishida S, Boudignon BM, Burghardt A, Elalieh HZ, Hamilton MM, Majumdar S, Halloran BP, Clemens TL, Bikle DD. IGF-I receptor is required for the anabolic actions of parathyroid hormone on bone. J Bone Miner Res. 2007;22:1329-1337.

60 Zhao G, Monier-Faugere MC, Langub MC, Geng Z, Nakayama T, Pike JW, Chernausek SD, Rosen CJ, Donahue LR, Malluche HH, Fagin JA, Clemens TL. Targeted overexpression of insulin-like growth factor I to osteoblasts of transgenic mice: increased trabecular bone volume without increased osteoblast proliferation. 
Endocrinology. 2000;141:2674-2682

61 Dallas SL, Bonewald LF. Dynamics of the transition from osteoblast to osteocyte. Ann N Y Acad Sci. 2010;1192: 437-443.

62 Bonewald LF. The amazing osteocyte. J Bone Miner Res. 2011;26: 229-238.

63 Sheng MH, Zhou XD, Bonewald LF, Baylink DJ, Lau KH. Disruption of the insulin-like growth factor-1 gene in osteocytes impairs developmental bone growth in mice. Bone. 2013;52: 133-144.

64 Lau KH, Baylink DJ, Zhou XD, Rodriguez D, Bonewald LF, Li Z, Ruffoni D, Muller R, Kesavan C, Sheng MH. Osteocyte-derived insulin-like growth factor I is essential for determining bone mechanosensitivity. Am J Physiol Endocrinol Metab. 2013;305: E271-E281.

65 Wang Y, Nishida S, Elalieh HZ, Long RK, Halloran BP, Bikle DD. Role of IGF-I signaling in regulating osteoclastogenesis. J Bone Miner Res. 2006;21:1350-1358.

66 Teitelbaum SL, Ross FP. Genetic regulation of osteoclast development and function. Nat Rev Genet. 2003;4:638-649.

67 Zhao C, Irie N, Takada Y, Shimoda K, Miyamoto T, Nishiwaki T, Suda T, Matsuo K. Bidirectional ephrinB2-EphB4 signaling controls bone homeostasis. Cell Metab. 2006;4:111-121.

68 Yakar S, Courtland HW, Clemmons D. IGF-1 and bone: New discoveries from mouse models. J Bone Miner Res. 2010;25:25432552 .

69 Barnard R, Haynes KM, Werther GA, Waters MJ. The ontogeny of growth hormone receptors in the rabbit tibia. Endocrinology. 1988;122:2562-2569.

70 DiGirolamo DJ, Mukherjee A, Fulzele K, Gan Y, Cao X, Frank SJ, Clemens TL. Mode of growth hormone action in osteoblasts. J Biol Chem. 2007;282:31666-31674.

71 Gan Y, Zhang Y, Digirolamo DJ, Jiang J, Wang X, Cao X, Zinn KR, Carbone DP, Clemens TL, Frank SJ. Deletion of IGF-I receptor (IGF-IR) in primary osteoblasts reduces GH-induced STAT5 signaling. Mol Endocrinol. 2010;24: 644-656.

72 Wu Y, Sun H, Basta-Pljakic J, Cardoso L, Kennedy OD, Jasper H, Domene H, Karabatas L, Guida C, Schaffler MB, Rosen CJ, Yakar S. Serum IGF-1 is insufficient to restore skeletal size in the total absence of the growth hormone receptor. J Bone Miner Res. 2013; 28:1575-1586.

73 Alexander JM, Bab I, Fish S, Muller R, Uchiyama T, Gronowicz G, Nahounou M, Zhao Q, White DW, Chorev M, Gazit D, Rosenblatt M. Human parathyroid hormone 1-34 reverses bone loss in ovariectomized mice. J Bone Miner Res. 2001;16: 1665-1673.

74 Dempster DW, Cosman F, Kurland ES, Zhou H, Nieves J, Woelfert L, Shane E, Plavetic K, Muller R, Bilezikian J, Lindsay R.
Effects of daily treatment with parathyroid hormone on bone microarchitecture and turnover in patients with osteoporosis: a paired biopsy study. J Bone Miner Res. 2001;16:1846-1853.

75 Kostenuik PJ, Harris J, Halloran BP, Turner RT, Morey-Holton ER, Bikle DD. Skeletal unloading causes resistance of osteoprogenitor cells to parathyroid hormone and to insulin-like growth factor-I. J Bone Miner Res. 1999;14:21-31.

76 Jilka RL, Weinstein RS, Bellido T, Roberson P, Parfitt AM, Manolagas SC. Increased bone formation by prevention of osteoblast apoptosis with parathyroid hormone. J Clin Invest. 1999;104:439446.

77 Rubin MR, Cosman F, Lindsay R, Bilezikian JP. The anabolic effects of parathyroid hormone. Osteoporos Int. 2002;13:267-277.

78 Lee SK, Lorenzo JA. Parathyroid hormone stimulates TRANCE and inhibits osteoprotegerin messenger ribonucleic acid expression in murine bone marrow cultures: correlation with osteoclastlike cell formation. Endocrinology. 1999;140:3552-3561.

79 Ma YL, Cain RL, Halladay DL, Yang X, Zeng Q, Miles RR, Chandrasekhar S, Martin TJ, Onyia JE. Catabolic effects of continuous human PTH (1--38) in vivo is associated with sustained stimulation of RANKL and inhibition of osteoprotegerin and gene-associated bone formation. Endocrinology. 2001;142:40474054.

80 Canalis E, Centrella M, Burch W, McCarthy TL. Insulin-like growth factor I mediates selective anabolic effects of parathyroid hormone in bone cultures. J Clin Invest. 1989;83:60-65.

81 Ishizuya $\mathrm{T}$, Yokose $\mathrm{S}$, Hori $\mathrm{M}$, Noda $\mathrm{T}$, Suda $\mathrm{T}$, Yoshiki $\mathrm{S}$, Yamaguchi A. Parathyroid hormone exerts disparate effects on osteoblast differentiation depending on exposure time in rat osteoblastic cells. J Clin Invest. 1997;99:2961-2970.

82 Bikle DD, Wang Y. Insulin like growth factor-I: a critical mediator of the skeletal response to parathyroid hormone. Curr Mol Pharmacol. 2012;5:135-142.

83 Miyakoshi N, Richman C, Kasukawa Y, Linkhart TA, Baylink DJ Mohan S. Evidence that IGF-binding protein-5 functions as a growth factor. J Clin Invest. 2001;107:73-81.

84 Yamaguchi M, Ogata N, Shinoda Y, Akune T, Kamekura S, Terauchi Y, Kadowaki T, Hoshi K, Chung UI, Nakamura K, Kawaguchi H. Insulin receptor substrate-1 is required for bone anabolic function of parathyroid hormone in mice. Endocrinology. 2005;146:2620-2628.

85 Yakar S, Bouxsein ML, Canalis E, Sun H, Glatt V, Gundberg C, Cohen P, Hwang D, Boisclair Y, Leroith D, Rosen CJ. The ternary IGF complex influences postnatal bone acquisition and the skeletal response to intermittent parathyroid hormone. J Endocrinol. 2006;189:289-299. 